\title{
ASSESMENT OF HEPATOPROTECTIVE ACTIVITY OF ROOTS AND BARKS OF ACHYRANTHES ASPERA IN CARBON TETRACHLORIDE-INDUCED HEPATOTOXICITY IN RATS
}

\author{
Nahian Fyrose Fahim*, Zakia Sultana Sathi \\ Department of Pharmacy, Daffodil International University, Dhaka, Bangladesh. \\ *To whom correspondence should be addressed. Email: fyrose.ph@diu.edu.bd
}

This is an open access article distributed under the Creative Commons Attribution License, which permits unrestricted use, distribution, and reproduction in any medium, provided the original work is properly cited.

\section{ARTICLE DETAILS}

Edited by:

Md. Mahmudul Hasan, Jessore University of Science and Technology, Jessore-7408, Bangladesh. Email: drhasan_nft@just.edu.bd

Reviewed by:

1. Md. Rausan Zamir

Daffodil International University

Dhaka, Bangladesh

Email:

drzamir@daffodilvarsity.edu.bd

2. Md. Ferdous Khan

North South University

Dhaka, Bangladesh

Email:khan.ferdous@northsouth.edu

Received 10 May 2018

Revised 01 June 2018

Accepted 12 June 2018

Available online 1 July 2018

\section{ABSTRACT}

Carbon tetrachloride (CCl4) is a colorless liquid organic compound which is used for household work. Mainly liver and kidney of human are the major organs for CCl4 toxicity. Liver can damage after 24 hours of CCl4 ingestion and can cause severe fatal symptoms including painful swollen liver, hemorrhages, hepatic coma leading to death. We examined the effect of CCl4 on rat liver. Serum glutamic pyruvic transaminase (SGPT) and serum bilirubin levels are used as a biomarker for the hepatotoxicity. Our goal was to determine the effect of SGPT and bilirubin level by using methanolic extract of Achyranthes aspera (Amaranthaceae) roots and barks on CCl4 induced rats. After completing the fractionation process these extracts was induced in the rat's body in a dose dependent manner. Our result demonstrated that carbon tetrachloride caused the hepatotoxicity in rats where $1 \mathrm{ml} / \mathrm{kg}$ body weight of carbon tetrachloride significantly increased the SGPT and bilirubin level in one day treatment, while $0.25 \mathrm{ml} / \mathrm{kg}$ and 0.50 $\mathrm{ml} / \mathrm{kg}$ body weight of CCl4 on one day treatment did not have significant effect on SGPT and bilirubin level. But the low dose of $\mathrm{CCl} 4$ such as $0.5 \mathrm{ml} / \mathrm{kg}$ of body weight for longer period treatment caused the hepatotoxicity. CCl4 induced controlled group was treated with dexamethasone $2.0 \mathrm{mg} / \mathrm{kg}, 4 \mathrm{mg} / \mathrm{kg}, 6.0 \mathrm{mg} / \mathrm{kg}, 8 \mathrm{mg} / \mathrm{kg}$ body weight to compare with plant extract activity. A significant result was found that the methanolic extract of root is responsive against CCl4 induced hepatotoxicity where the doses were $10 \mathrm{mg} / \mathrm{kg}, 20 \mathrm{mg} / \mathrm{kg}$ and $30 \mathrm{mg} / \mathrm{kg}$.

\section{KEYWORDS}

Hepatotoxicity, Carbon tetrachloride, Achyranthes aspera, Bilirubin, Serum glutamic pyruvic transaminase.

\section{INTRODUCTION}

Based on a study, liver is one of the vital organs in human body having a major role for maintaining, regulating homeostasis of the body by metabolizing protein, fat and carbohydrate [1]. Study showed, continuous exposure of harmful metabolites, poisons and drugs can lead to various acute and chronic liver diseases like hepatitis, cirrhosis, hepatotoxicity [2]. According to research, there are more than 100 types of environmental poisons which can cause liver disease. Carbon tetrachloride $\left(\mathrm{CCl}_{4}\right)$ is considered as one of the major poisons which cause severe hepatotoxicity after ingestion and inhalation in animal body [3]. Though a few data were found to identify the toxic effect of $\mathrm{CCl}_{4}$ in human, but current research reviled that this toxin may also cause harmful effect on human liver. After administration of $\mathrm{CCl}_{4}$ in rats increase oxidation of protein in the liver as a result oxidized protein accumulate in the liver. Oxidative damage to hepatocellular proteins may contribute to the pathogenesis of $\mathrm{CCl}_{4}$ induced liver injury. According to a scholar, an enzyme which is known as serum glutamic pyruvic transaminase normally present in liver. This enzyme is released into the blood when any unusual physiological, pathological changes and damaged occur in liver. As a result, the level of SGPT increases in the blood then normal value [4-6]. Serum glutamic oxaloacetate transaminase (SGOT) is another biomarker to identify liver diseases. It is released into the blood when cells that contain it are damaged. Bilirubin is the yellow breakdown product of normal heme catabolism the elevated levels of bilirubin may indicate certain diseases including hepatotoxicity.
The concept of herbal medicine and their use has been started since the ancient time. Based on research, direct use of herbs and extract of plants are widely using as drugs by ensuring safety and effectiveness to treat various types of diseases. In modern times herbs are the major source where we can synthesize and extract active metabolites [7]. In our study we have chosen Achyranthes aspera which is a perennial herb, $1-2 \mathrm{~m}$ in height commonly known as Rough Chaff Tree. This plants usually found as a weed on roadsides in South Asian region including Bangladesh [8]. By reviewing literature, we have found that this plant has so many medicinal properties including spermicidal, antipyretic and as a cardiovascular activity [9-11]. It is considered as traditional healer with antidiuretic, antidiabetic and hepatoprotective activity [12]. Dexamethasone is considered as one of the safest therapeutic agents to treat hepatic inflammation [13].

\section{MATERIALS AND METHOD}

\subsection{Chemicals}

Plant extract was prepared by following a standard process in the Daffodil International University medicinal chemistry laboratory. SGPT and Bilirubin reagent was collected from pharmacology research laboratory of Daffodil International University. Carbone tetrachloride and dexamethasone API were collected from the research laboratory of University of Rajshahi. Olive oil was purchased from surgical laboratories. 


\subsection{Preparation extract from plants}

After collection, barks and roots were grinded individually. The powdered barks about $230 \mathrm{gm}$ and root weight $97 \mathrm{gm}$ were taken separately in two colored reagent bottles. Almost 2-liter methanol was used to soak the sample. The sealed bottles were kept in dry and cool place for 1.5 weeks with occasional stirring and shaking. Both root and bark extract then filtered through cotton first then with Whatman No.1 filter paper. To obtain crude methanolic extract of roots and barks rotary evaporator was used under reduced pressure and $45^{\circ} \mathrm{C}-50^{\circ} \mathrm{C}$.

\subsection{Test Animals}

Male Wister albino rats, 3 to 5 weeks old and weighing between $75-140 \mathrm{~g}$ of both sexes were used in the experiments. Total number of rats (24) was collected from the Department of Pharmacy, Jahangirnagar University, Savar, Dhaka. All the rats were divided in to six groups 1 control and 5 $\mathrm{CCl}_{4}$ induced) each group having four rats. All the animals were kept in room temperature $22 \pm 3^{\circ} \mathrm{C}$ and relative humidity $65 \pm 5 \%$. A $12: 12$ hour, light: dark cycle was followed. All the experimental procedure and protocol used in the study were followed as international animal ethics committee for the purposive control.

\subsection{Stock Solution}

The Stock Solution was prepared by the ratio of Carbon tetra chloride: olive oil (1:3)

\subsection{Instrument}

Hypodermic syringes (1cc, 3cc) and insulin syringe were used. Butterfly needle tube and mouth gages were used for convenient administration of $\mathrm{CCl}_{4}$.

\subsection{Administration of $\mathrm{CCl}_{4}$}

$0.50 \mathrm{ml} / \mathrm{kg}$ body weight dose, were administered intra-peritoneal. All doses were single dose.

\subsection{Collection of serum}

After completing carbon tetra chloride treatment, the rats were sacrificed and $2-3 \mathrm{ml}$ of blood was collected directly from heart by syringes, centrifuged at $4000 \mathrm{rpm}$ for 30 minutes and the serum was obtained.

\subsection{Liver function test}

To asses liver damage by $\mathrm{CCl}_{4}$, the determination of enzyme levels was largely used. Based on a study, serum SGPT, bilirubin is the most important marker to diagnose hepatic damage because SGPT, SGOT and bilirubin release when liver is damaged by any toxins or pathological and physiological abnormalities [14]. In this study, an increase in the activities of SGPT and bilirubin in serum evidenced the $\mathrm{CCl}_{4}$-induced hepatocellular damage $[15,16]$. When $\mathrm{CCl}_{4}$ induced rats are treated with dexamethasone phosphate injection there was a significant decrease of SGPT and bilirubin level.

\subsection{Statistical analysis}

All the analysis for this experiment were performed by one-way ANOVA followed by Scheffe's post-hoc test. Values were expressed as mean \pm S.D. of four animals of each groups. Here we found $p$ - value is $<0.05$ which is significant.

\section{RESULTS}

Table 1: Level of SGPT on CCl4 induced rat compared with controlled group $\left(\left(37^{\circ} \mathrm{C}\right)\right.$

\begin{tabular}{|l|l|l|}
\hline SL & $\begin{array}{l}\text { SGPT level in controlled } \\
\text { group U/L }\end{array}$ & $\begin{array}{l}\text { SGPT level in } \mathbf{C C l}_{4} \text { induced } \\
\text { rat U/L }\end{array}$ \\
\hline 1 & $52 \pm 1$ & $121 \pm 3$ \\
\hline 2 & $59.5 \pm 1.5$ & $275 \pm 2$ \\
\hline 3 & $82 \pm .01$ & $198 \pm 3.2$ \\
\hline 4 & $71 \pm 2$ & $312 \pm 4$ \\
\hline
\end{tabular}

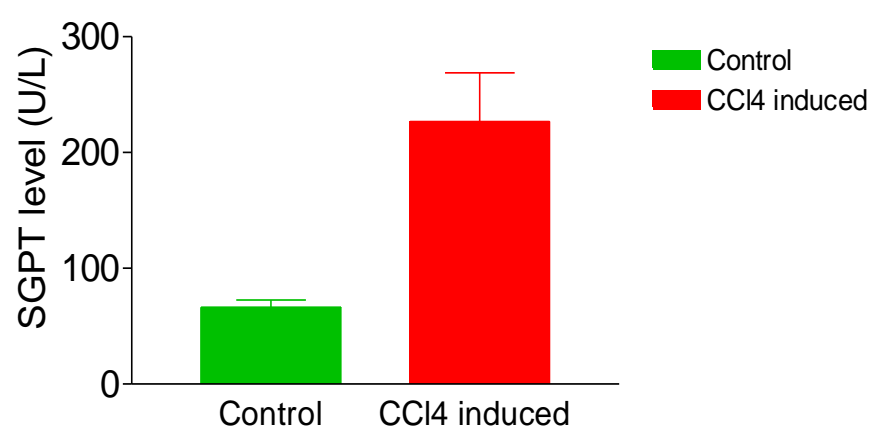

Figure 1: Level of SGPT of both controlled and $\mathrm{CCl}_{4}$ induced group of rat $\left(37^{\circ} \mathrm{C}\right)$

$0.5 \mathrm{ml} / \mathrm{kg}$ body weight $\mathrm{CCl} 4$ was injected in four different rats and after five days serum was collected from both controlled and induced group then SGPT and Bilirubin level was measured. From the above chart it has been seen that there is a significant difference of SGPT level among control group and $\mathrm{CCl}_{4}$ induced group of rat. The result was expressed in mean \pm S.D where $\mathrm{p}<0.05$

Table 2: Level of Bilirubin (mg/dl) CCl4 induced rat compared with controlled group

\begin{tabular}{|l|l|l|}
\hline & $\begin{array}{l}\text { Bilirubin level in controlled } \\
\text { group }\end{array}$ & $\begin{array}{l}\text { Bilirubin level in } \mathrm{CCl}_{4} \text { induced } \\
\text { rat }\end{array}$ \\
\hline 1 & $1.70 \pm .02$ & $9.21 \pm .041$ \\
\hline 2 & $3.60 \pm .1$ & $15 \pm .64 \pm .01$ \\
\hline 3 & $2.59 \pm .08$ & $18 \pm .023$ \\
\hline 4 & $2.2 \pm .031$ & $13 \pm .034$ \\
\hline
\end{tabular}

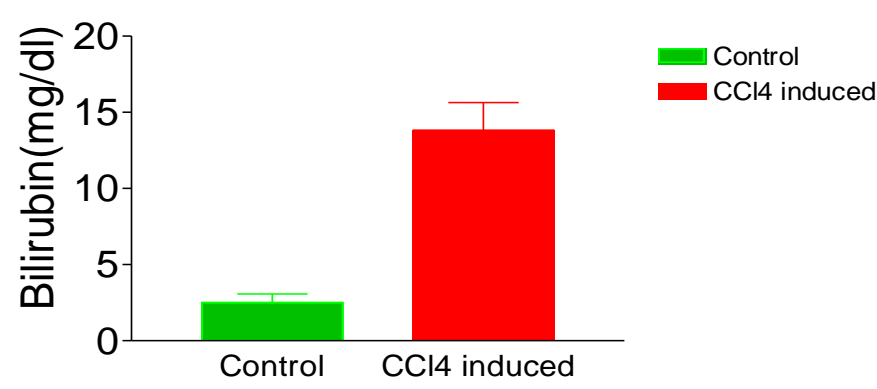

Figure 2: Level of Bilirubin of both controlled and $\mathrm{ccl}_{4}$ induced group of rats $\left(37^{\circ} \mathrm{C}\right)$

Effect of $\mathrm{CCl}_{4}(0.5 \mathrm{ml}$ per kg body weight) on liver enzyme, Bilirubin on rat. From the above chart it has been seen that there is a significant difference of Bilirubin level among control group and $\mathrm{CCl}_{4}$ induced group of rats.

3.1 Level of SGPT and Bilirubin on $\mathrm{CCl}_{4}$ induced rat compared with $\mathrm{CCl}_{4}$ induced rat treated with Dexamethasone

$0.5 \mathrm{ml} / \mathrm{kg}$ body weight in every single dose of each rat was injected then after 3 days dexamethasone was injected in four rats and other four was separated in another case. After waiting 2 days blood serum was collected from both groups individually to measure SGPT and Bilirubin

Table 3: SGPT and bilirubin in $\mathrm{CCl}_{4}$ induced rat treated with Dexamethasone

\begin{tabular}{|c|c|l|l|}
\hline & Dose $(\mathrm{mg} / \mathrm{kg})$ & SGPT level U/L & Bilirubin level $\mathrm{mg} / \mathrm{dl}$ \\
\hline 1 & 2 & $112.42 \pm 0.034$ & $2.10 \pm 0.021$ \\
\hline 2 & 4 & $123.86 \pm .42$ & $4.23 \pm 0.023$ \\
& & & \\
\hline 3 & 6 & $106.87 \pm .07$ & $3.40 \pm 0.01$ \\
\hline 4 & 8 & $96.265 \pm .31$ & $3.28 \pm .0211$ \\
\hline
\end{tabular}




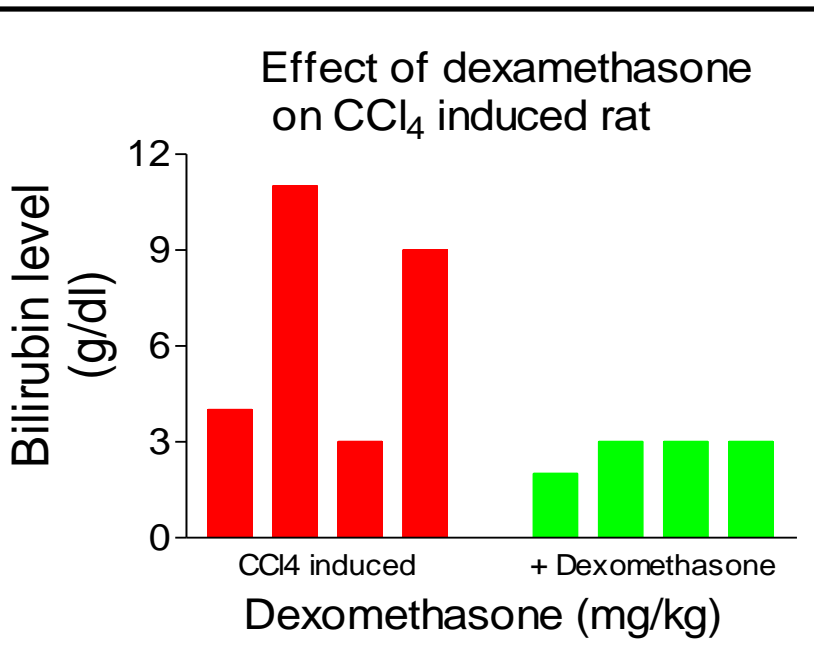

Figure 3: Comparison of bilirubin level after administration of dexamethasone in $\mathrm{CCl} 4$ induced rat.

Effect of Dexamethasone (2, 4, 6 and $8 \mathrm{ml} / \mathrm{kg}$ body weight) on liver enzyme, Bilirubin on rat. From the above chart we can see there is a significant difference of Bilirubin level among control group and dexamethasone induced group of rat.

\section{Effect of dexamethasone on SGPT level}

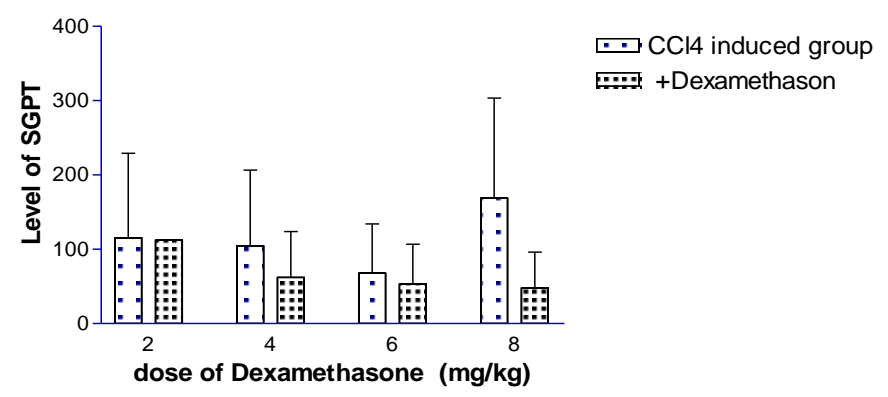

Figure 4: Level of SGPT after administration of Dexamethasone.

Figure four shown that the effect of dexamethasone $(2,4,6,8 \mathrm{ml}$ per $\mathrm{kg}$ body weight) on liver enzyme SGPT on rat. From the above chart it has been observed that there is a significant difference of SGPT level among $\mathrm{CCl}_{4}$ induced group of rat and after administration of Dexamethasone in $\mathrm{CCl}_{4}$ induced rat. The result was expressed in mean \pm S.D.

3.2 Level of SGPT and Bilirubin on $\mathrm{CCl}_{4}$ induced rat compared with $\mathrm{CCl}_{4}$ induced rat treated with Plant extract (roots and barks)

Table 4: Effect of Plant Extract (root) on SGPT, Bilirubin level of CCl4 induced rat

\begin{tabular}{|l|l|l|l|}
\hline & Dose $(\mathrm{mg} / \mathrm{kg})$ & SGPT level U/L & Bilirubin level mg/dl \\
\hline 1 & 10 & $201.34 \pm 0.21$ & $2.1 \pm .033$ \\
\hline 2 & 20 & $119.09 \pm .4$ & $1.876 \pm .065$ \\
\hline 3 & 30 & $109.76 \pm .54$ & $1.843 \pm .034$ \\
\hline
\end{tabular}

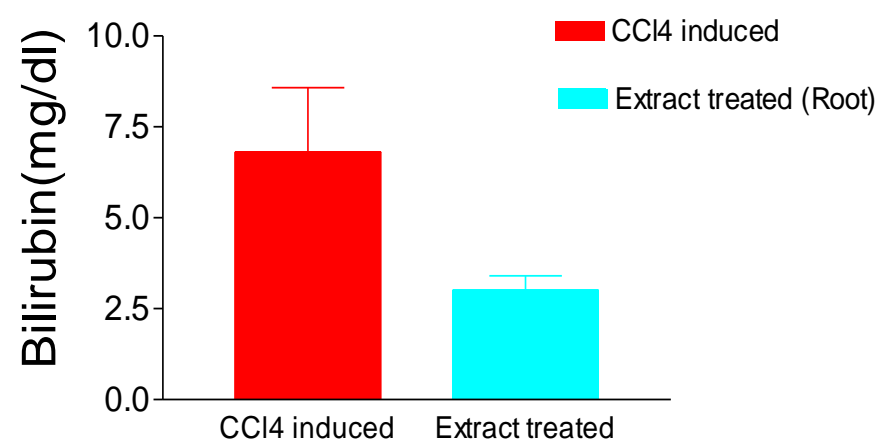

Figure 5: Examination of bilirubin level after administration of plant extract (root) on $\mathrm{CCl}_{4}$ induced rat
Figure five is showing that the effect of dexamethasone $(2,4,6,8 \mathrm{ml}$ per $\mathrm{kg}$ body weight) on liver enzyme SGPT on rat. From the above chart it has been observed that there is a significant difference of SGPT level among CCl4 induced group of rat and after administration of Dexamethasone in CCl4 induced rat. The result was expressed in mean \pm S.D.

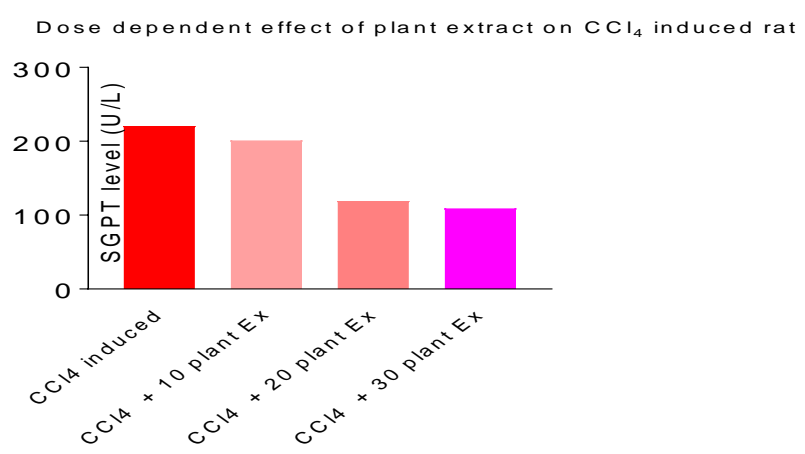

Figure 6: Examination of SGPT level after administration of plant extract (root) on $\mathrm{CCl}_{4}$ induced rat

Effect of Achyranthes aspera (root) on SGPT on rat. From the above chart we can see there is a significant difference of SGPT level among control group and $\mathrm{CCl} 4$ induced group of rat. Analysis was performed by one-way ANOVA followed by Scheffe's post-hoc test

Table 5: Effect of Plant Extract on SGPT, Bilirubin level of CCl4 induced rat (Bark)

\begin{tabular}{|l|l|l|l|}
\hline & Dose $(\mathrm{mg} / \mathrm{kg})$ & SGPT level U/L & Bilirubin level mg/dl \\
\hline 1 & 10 & 223.2 & $6.05 \pm .02$ \\
\hline 2 & 20 & 167.82 & $4.04 \pm .034$ \\
\hline 3 & 30 & 190.4 & $7.5 \pm 1$ \\
\hline
\end{tabular}

After administration of bark extract in a dose dependent manner $(10 \mathrm{mg} / \mathrm{kg}, 20 \mathrm{mg} / \mathrm{kg}, 30 \mathrm{mg} / \mathrm{kg})$ there was no significant change occur.

\section{DISCUSSION}

Based on a research, liver damage induced by carbon tetrachloride is commonly used model for the screening of hepatoprotective activity of different active compounds [17]. In modern research many plants were tested for potential antioxidant and hepatoprotective liver damage in experimental animal model [18]. $\mathrm{CCl}_{4}$ hepatotoxicity model is widely using for this kind of studies. CCl4 metabolically activated to form trichloromethyl free radical $\left(\mathrm{CCl}_{3}\right)$ which bind with cellular lipids and proteins which cause the structural change of endoplasmic reticulum and other membrane. Study showed, loss of activation of metabolic enzyme, reduction of protein synthesis and loss of glucose 6- phosphatase activation cause liver damage [19]. In this study (table 1 and table 2) it has been found that after administration of $\mathrm{CCl}_{4} 1 \mathrm{mg} / \mathrm{kg}$ body weight the level of SGPT and bilirubin increased. Various studies indicate that Achyranthus aspera has so many pharmacological effects on rats including hepatoprotective activity on paracetamol and sodium nitrate induced rats on the other hand this study indicates that with the increase of plant extract dose the level of SGPT and bilirubin decreased in a significant rate (Figure 5 and 6) [20-22]. By reviewing literature, we have seen amelioration effects against $\mathrm{CCl}_{4}$-induced hepatocarcinogenesis in Swiss albino rats where the whole plant extract of Achyranthes aspera was used [23]. We used the methanolic extract of root and bark of Achyranthus aspera separately. From the above figures and tables, it can be said there is a significant difference of bilirubin and SGPT level among control group and $\mathrm{CCl}_{4}$ induced group of rat after treating with methanolic extract of roots of Achyranthus aspera. But there is no significant change occur by treating with bark of Achyranthes aspera in $\mathrm{CCl}_{4}$ induced hepatotoxicity [24]. It has been reported that the methanolic extract of leaf of this plant shows a hepatoprotective activity in rifampine induced albino rats where the level of SGPT, SGOT and total bilirubin decreases with the increase of dose but in this study the effect of roots and barks has been examined separately $[25,26]$.

\section{CONCLUSION}

Present study demonstrated that carbon tetrachloride induction causes prominent increase of the liver enzymes such as SGPT, which may be due 
to the decrease of antioxidant system in serum in $\mathrm{CCl}_{4}$ induced rat and oxidative stress is an important mechanism of organ damage. The detailed mechanisms are worthy of further investigation and knowledge. We chose the natural source such as Achyranthes aspera (Family: Amaranthaceae) depending upon its potential activities through literature review. A positive effect has been observed for plant extract against $\mathrm{CCl}_{4}$ induced hepatotoxicity. In conclusion, we can say methanolic extract of roots of Achyranthus aspera is a prominent source to treat $\mathrm{CCl}_{4}$ induced liver damage. By comparing with standard (dexamethasone) is has been revealed that herbal products specially plant source is a great source for treating hepatic diseases. We will extend our research to find out the active compounds which are mainly responsible for hepatoprotective activity.

\section{ACKNOWLEDGEMENT}

We are thankful to Daffodil International University, Department of Pharmacy for providing me all sorts of support to complete this research work.

\section{REFERENCES}

[1] Ward, F.M., Daly, M.J. 1999. Hepatic disease in clinical pharmacy and therapeutics. 14 .

[2] Chalasani, N., Aljadhey, H., Kesterson, J., Murray, M.D., Hall, S.D. 2004. Patients with elevated liver enzymes are not at higher risk for statin hepatotoxicity. Gastroenterology, 126 (5), 1287-1292.

[3] Karan, M., Vasisht, K. Handa, S.S. 1999. Antihepatotoxic activity of Swertia chirata on carbon tetrachloride induced hepatotoxicity in rats. Phytotherapy Research: An International Journal Devoted to Pharmacological and Toxicological Evaluation of Natural Product Derivatives, 13 (1), 24-30.

[4] Kaplowitz, N., 2002. Biochemical and cellular mechanisms of toxic liver injury. In Seminars in liver disease, 22 (2), 137-144.

[5] Balazs, T., Airth, J.M., Grice, H.C. 1962. The use of the serum glutamic pyruvic transaminase test for the evaluation of hepatic necrotropic compounds in rats. Canadian journal of biochemistry and physiology, 40 (1), 16

[6] Al-Assaf, A.H., 2013. Preventive effect of corosolic acid on lipid profile against carbon tetrachloride: Induced hepatotoxic rats. Pakistan Journal of Nutrition, 12,748-52.

[7] Mukherjee, P.K. 2008. Quality control of herbal drugs. Business Horizon Pharmaceutical Publishers, 13.

[8] Srivastav, S., Singh, P., Mishra, G., Jha, K.K., Khosa, R.L., 2011. Achyranthes aspera-An important medicinal plant: A review. Journal of Natural Product and Plant Resources, 1 (1), 1-14.

[9] Vetrichelvan, T., Jegadeesan, M. 2003. Effect of alcohol extract of Achyranthes aspera Linn. on acute and subacute inflammation. Phytotherapy Research: An International Journal Devoted to Pharmacological and Toxicological Evaluation of Natural Product Derivatives, 17 (1), 77-79.

[10] Srivastav, S., Singh, P., Mishra, G., Jha, K.K., Khosa, R.L., 2011. Achyranthes aspera-An important medicinal plant: A review. Journal of Natural Product and Plant Resources, 1 (1), 1-14.

[11] Gupta, R.K. 2010. Medicinal and Aromatic plants, CBS publishers and distributors, 1st Edition, 116-117.

[12] Girach Aminuddin, R.D., Khan, S.A. 1992. Ethnomedicinal Uses of Achyranthes sapera L. in Orissa (India). International Journal of Pharmacognosy, 30 (2), 113-115.
[13] Abrams, M.T., Koser, M.L., Seitzer, J., Williams, S.C., DiPietro, M.A., Wang, W., Shaw, A.W., Mao, X., Jadhav, V., Davide, J.P., Burke, P.A., 2010. Evaluation of efficacy, biodistribution, and inflammation for a potent siRNA nanoparticle: Effect of dexamethasone co-treatment. Molecular therapy, 18 (1), 171-180.

[14] Reitman, S., Frankel, S. 1957. A colorimetric method for the determination of serum glutamic oxalacetic and glutamic pyruvic transaminases. American journal of clinical pathology, 28 (1), 56-63.

[15] Drotman, R.B., Lawhorn, G.T. 1978. Serum enzymes as indicators of chemically induced liver damage. Drug and chemical toxicology, 1 (2), 163-171.

[16] Pari, L., Amali, D.R. 2005. Protective role of tetrahydrocurcumin (THC) an active principle of turmeric on chloroquine induced hepatotoxicity in rats. Journal of Pharmaceutical Sciences, 8 (1), 115-23.

[17] Recknagel, R.O., Glende Jr, E.A., Dolak, J.A., Waller, R.L. 1989. Mechanisms of carbon tetrachloride toxicity. Pharmacology and therapeutics, 43 (1), 139-154.

[18] Suja, S.R., Latha, P.G., Pushpangadan, P., Rajasekharan, S. 2004. Evaluation of hepatoprotective effects of Helminthostachys zeylanica. Hook against carbon tetrachloride-induced liver damage in Wistar rats. Journal of Ethnopharmacology, 92 (1), 61-66.

[19] Ahsan, M.R., Monirul Islam, K.M., Bulbul, I.J., Musaddik, M.A., Haque, E. 2009. Hepatoprotective activity of methanol extract of some medicinal plants against carbon tetrachloride-induced hepatotoxicity in rats. European Journal of Scientific Research, 37 (2), 302-310.

[20] Sharma, A., Chakraborti, K.K., Handa, S.S. 1991. Anti-hepatotoxic activity of some Indian herbal formulations as compared to silymarin. Fitoterapia, 62, 229-235.

[21] Subramonium, A.P., Pushpangadan. 1990. Development of phytomedicines for liver diseases. Indian Journal of Pharmacology, 31, 166-175.

[22] Sherif, I.O., Al-Gayyar, M.M. 2013. Antioxidant, antiinflammatory and hepatoprotective effects of silymarin on hepatic dysfunction induced by sodium nitrite. European cytokine network, 24 (3), 114-21.

[23] Kartik, R., Rao, C.V., Trivedi, S.P., Pushpangadan, P., Reddy, G.D. 2010. Amelioration effects against $\mathrm{N}$-nitrosodiethylamine and CCl4induced hepatocarcinogenesis in Swiss albino rats by whole plant extract of Achyranthes aspera. Indian Journal of Pharmacology, 42 (6), 370-375.

[24] Girach, R.D., Khan, A.S.A. 1992. Ethno medicinal uses of Achyranthes aspera leaves in Orissa (India) International Journal of Pharmacogny, 30, 113-5.

[25] Melgert, B.N., Olinga, P., Jack, V.K., Molema, G., Meijer, D.K.F., Poelstra, K. 2000. Dexamethasone coupled to albumin is selectively taken up by rat nonparenchymal liver cells and attenuates LPS-induced activation of hepatic cells. Journal of Hepatology, 32, 603-611.

[26] Abrams, M.T., Koser, M.L., Seitzer, J., Williams, S.C., DiPietro, M.A., Wang, W., Shaw, A.W., Mao, X., Jadhav, V., Davide, J.P., Burke, P.A. 2010. Evaluation of efficacy, biodistribution, and inflammation for a potent siRNA nanoparticle: Effect of dexamethasone co-treatment. Molecular therapy, 18 (1), 171-180. 